\title{
Effect of Anthropogenic Activities on Mangrove Crab Diversity in Cameroon Atlantic Coast
}

\author{
Vanessa Maxemilie Ngo-Massou ${ }^{1,2}$, Martin Kenne ${ }^{3 *}$, Alain Bertrand Dongmo ${ }^{3}$ \\ ${ }^{1}$ Department of Botany, Faculty of Sciences, University of Douala, Douala-Cameroon. \\ ${ }^{2}$ Department of Biological Sciences, High Teacher's Training College, University of Yaounde I, \\ Cameroon, \\ ${ }^{3}$ Department of Biology of Animal Organisms, Faculty of Science, University of Douala, \\ Douala-Cameroon \\ martin.kenne@univ-douala.com
}

\begin{abstract}
Abstrat: Crabs have a significant ecological role on mangrove structure and function. Their adaptations related to human pressures are poorly studied. This survey aims to determine the impact of mangrove degradation on crab diversity. Fourteen mangrove stands dominated by Rhizophora spp. were selected in some localities from Limbe to Kribi. Three methods were used for sampling (excavation, sight harvest and visual count) in $4 \times 4 \mathrm{~m}^{2}$ plots. The impact of human pressures on mangrove was evaluated using informal interviews, semi-structured questionnaire, field data and observations. In all, 25 species belonging to 16 genera and 9 families were collected. Sesarmidae family (10 species) were the most represented and abundant taxa (80.7\%). Perisesarma alberti was the most frequent species $(C i=94.11 \%)$, while Helice sp., Macrophthalmus sp., Maja squinado, Ocypode africana, Panopeus africanus, Portunus validus, and Sesarma spp. were rare $(\mathrm{Ci}=5.88 \%)$. Wood harvested was largely practiced in all stands and Rhizophora spp. appears overexploited everywhere. According to the deforestation level, Cardisoma guanhami, Helice sp., Macrophthalmus sp., Panopeus africanus and Sesarma spp. must be considered as the indigenous species of non-degraded stands. The abundance of Chiromantes buettikoferi, C. angolense, Metagrapsus curvatus and Perisesarma alberti decreased in perturbed zones. Sesarmid and Portunid crabs were significantly impacted by deforestation throughout the areas. In relation with crab distribution, the indigenous crabs (Helice sp. and Maja squinado) of the Rhizophora zone and the terrestrial crabs (Cardisoma spp. and Uca tangeri) appeared to be the major threatened species.
\end{abstract}

Keywords: abundance, crab diversity, human activities, threatened species.

\section{INTRODUCTION}

Mangrove species are dominated by a diverse and distinctive macro-faunal vertebrate and invertebrate assemblages which exert a strong influence on the ecosystem functioning and regulate the mangrove forest productivity $[1,2]$. Among the resident mangrove fauna, brachyuran crabs are undoubtedly the most important component, high in species number, abundance and biomass compared with many other animals [3,4]. About 6,793 valid species, including 93 families and 38 subfamilies have so far been discovered worldwide [5]. In this group, fiddler crabs particularly are considered to be the most abundant [6]. They form an important link between the primary detritus at the base of the food web and consumers of higher trophic levels [7].

Crabs have a wide range of adaptations that allow them to colonize niches created by the complex interaction of vegetation structure and tidal regime [8]. Furthermore, they play a pivotal role in mangrove ecosystem functioning $[9,10]$. Crab burrowing activities significantly decrease ammonium and sulfite concentrations in mangrove soils, thus positively benefiting mangroves' productivity [11]. By consuming litter, crabs can promote nutrient mineralization and recycling within the forest. Furthermore, their role as bioturbators doubtlessly contributes to alter physiochemical characteristics of the soil and enhance its capability to retain organic carbon $[12,13]$. More recently, the beneficial effect of $U c a$ spp. activities on mangrove soil biogeochemistry can be strongly impaired by organic waste discharge was showed [4].

More than $90 \%$ of world's mangroves are located in developing countries, where impoverished human populations depend on their resources for subsistence [14]. Human impacts on mangroves, 
including climate change, have receive much attention of late mainly because mangrove deforestation is occurring at a rate of 1-2\% per year, which implies that most forests will disappear within century [15]. Mangroves in Cameroon represent the most thriving ecosystems and the most impacted due to population increase and an oil platform close to the Gulf of Guinea [16]. Many areas have been strongly affected and the rapid population increase has especially lead to large-scale deforestation due to a growing demand for housing land and logging cultivation [17, 18]. This urbanization transformed hectares of forest characterised by mature stands of mangrove trees such as Rhizophora spp. and Avicennia sp. into highly degraded areas with a dramatic change in botanical assemblages [19].

Studies concerning the effects of industrial and/or domestic wastewater on crab diversity are recent [4, 20,21]. The consequences of deforestation on mangrove fauna have not yet been documented in West Africa. The significant role of crabs as a engineer species starts to be recognized, but their ecological answers with respect to human pressures are poorly known compared to other aspects of their life such as diversity, distribution, sex ratio, ecological roles, feeding ecology, plant periodical migrations, physiological adaptations, domestic wastewater effects, $\ldots[22,23,24,25,26,27,28,29,30]$. So, the aim of this study is to determine the impact of human pressures on mangrove crab biodiversity in Cameroon.

\section{Materials And Methods}

\subsection{Study Site}

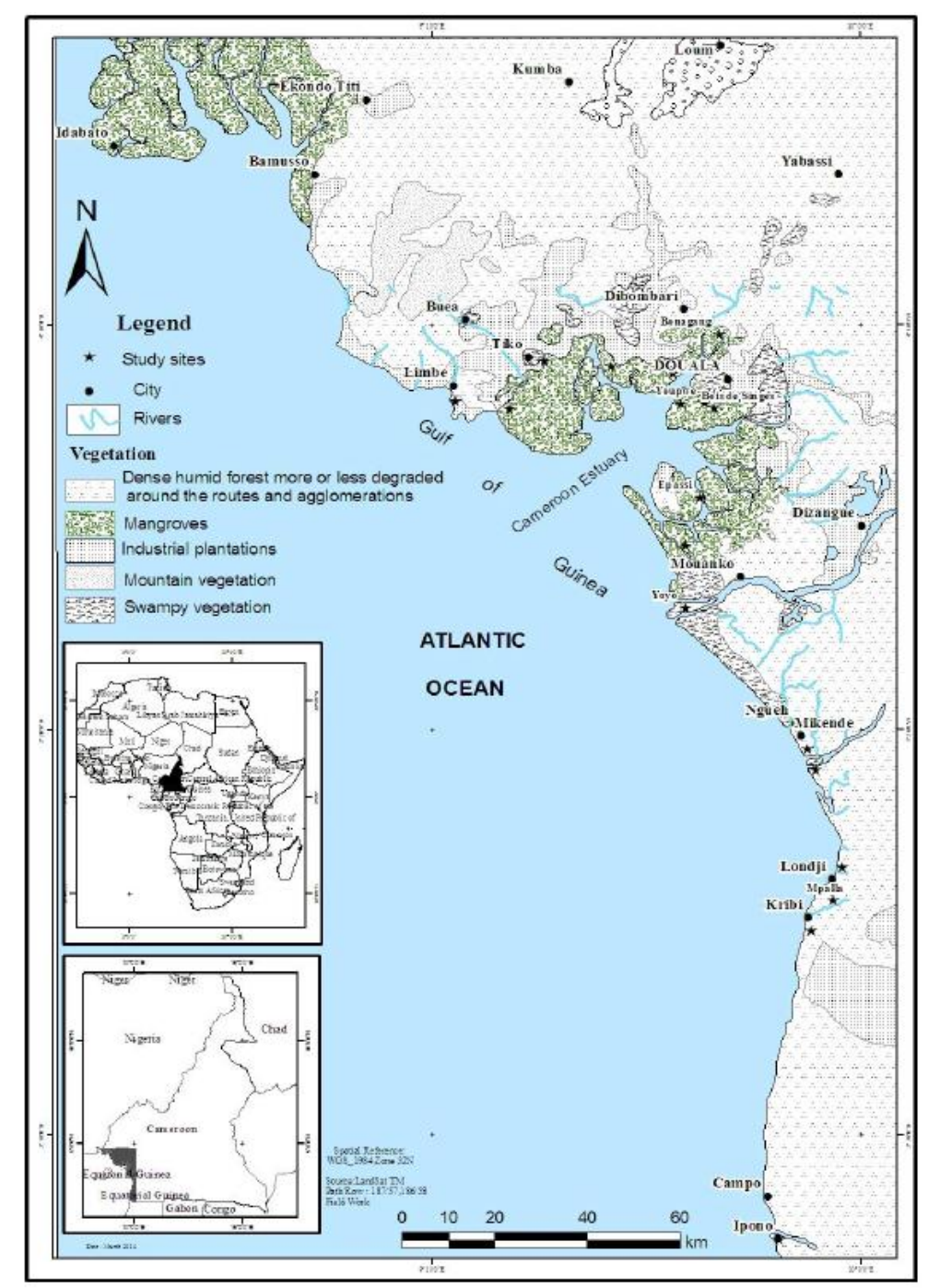

Figure1. Location of mangrove areas in Cameroon Atlantic coast [31])

The study was carried out in Cameroon in localities situated between Limbe (North Region) and Kribi (South Region) $\left(2^{\circ} 61^{\prime}-3^{\circ} 40^{\prime} \mathrm{N}\right.$ and $\left.9^{\circ} 10^{\prime}-9^{\circ} 55^{\prime} \mathrm{E}\right)$ where mangrove stands are dominated by Rhizophora spp. Fourteen study stations (Limbe, Tiko, Wouri estuary, Mouanko, Londji and Kribi) were selected based on accessibility and floristic composition (Figure 1). The area is dominated by 
two types of climate. In the north and center part, the climate belongs to a particular equatorial regime called Cameroonian regime, characterized by a long rainy season (March-November) and a short dry season (December-February) with annual average temperature of about $26.7{ }^{\circ} \mathrm{C}$ [17]. In the south Region (Kribi), the climate is of a typical equatorial regime with four seasons (two rainy seasons and two dry seasons well individualized), marked by high and stable temperatures of about $28.7^{\circ} \mathrm{C}$.

Heavy annual rainfalls are observed from more than 5,000 $\mathrm{mm}$ at Limbe area and decreased to about $3,000 \mathrm{~mm}$ at Kribi area. In the spring tide, the tidal regime reaches $3 \mathrm{~m}$ in the Cameroon Estuary, 1.2 $\mathrm{m}$ in the mouth of Nyong and $1.5 \mathrm{~m}$ in Kribi [32]. The annual variation in salinity ranges between 0 and $20 \%$. The relative humidity is always close to the saturation rate. Soils are grey or black muds, silty, sandy or clay texture, and deriving from fluvial sediments. The content of organic matter is relatively low, 1 to $3 \%$ with carbon: nitrogen ratio $(\mathrm{C}: \mathrm{N})$ often lower than 10 in the whole area.

The flora consists essentially of tree species. The herbaceous stratum represents $<1 \%$ of the entire vegetation. However, the flora remains poor with Rhizophora racemosa GF Meyer being largely the dominant vegetation in all sites. The faunal component includes vertebrates, such as birds, reptiles and fish, and a wide range of invertebrates, mainly crabs and molluses which constitute the bulk of benthic diversity in the region [28]

\subsection{Station Characterization}

The methodology of evaluation used two generally known methods. A participative process (Buttom up) based on specific investigations with the populations followed by an analysis of field data and observations (Down up) (Appendix 1). A participative process data were generated through interviews and semi-structured questionnaire of local residents [17]. The households were sampled opportunistically (i.e., respondents encountered in their houses were interviewed whereas people away from their home (if the residents were still carrying out their occupation) were not questioned). To avoid recurrent information, only one person ( $>20$ years of age) per house was questioned. For field data and observations analysis, deforestation state into station areas was evaluated using the following formula:

\section{Degradation state $D(\%)=(r / R) \times 100$ \\ r: distance of mangrove destroyed during 5 years \\ R: distance of the initial mangrove 5 years ago.}

Stations are then classified into two groups according to values of the degradation state: D > 50\% indicates disturbed zones and $\mathrm{D}<50 \%$ for not disturbed zones.

\subsection{Crabs Survey}

Mangrove forest was divided into three main zones: landward fringe, tree species belts, sand flat or mudflat. In each station, $500 \mathrm{~m}$ line transect was established across the zone according to the vegetation spread. To assess the abundance and density of the crab populations, crab individuals were sampled in randomly selected $4 \times 4 \mathrm{~m}$ plots along the transect, using three techniques (visual count [23], excavation [33] and crab harvest [34]) depending on species found. Harvested crabs were sedated in cold water for a few minutes, washed and stored into $70 \%$ alcohol or in a field freezer for later processing. Identifications have been made in the field or later in laboratory using some identification keys [35,5]. Undetermined specimens were brought to the Royal Museum for Central Africa (Belgium) for identification.

\subsection{Data Analysis}

Data a given in terms of percentages (qualitative variables), mean \pm standard deviation (quantitative variables) or absolute and relative densities (absolute density $=$ number of individuals $/ \mathrm{m}^{2}$; relative density $=$ number of individuals per species/total number of harvested individuals). A comparison of percentages is performed using the khi-square test. Two mean values were compared using the parametric student t-test (when normality and equal variance tests passed) or the nonparametric Mann-Whitney rang sum test (when conditions do not pass). Several mean values are compared using the one way ANOVA test. The relationship between environmental parameters and biotic variables were evaluated using Pearson's correlation.

The occurrence indices of each species was determined using the formula: $\mathbf{C}_{\mathbf{i}}=\mathbf{N}_{\mathbf{i}} \mathbf{x} \mathbf{1 0 0 / N}$ [36] and interpreted as follow: (1) $\mathrm{Ci} \leq 10$ for rare species, (2) $10<\mathrm{C}_{\mathrm{i}} \leq 25$ indicates accessory species, (3) 50 
$<\mathrm{C}_{\mathrm{i}} \leq 75$ for frequent or common species, (4) $75<\mathrm{C}_{\mathrm{i}}<100$ indicates constant species and (5) $\mathrm{C}_{\mathrm{i}}=$ 100 indicates omnipresent species.

Statistical analysis was performed using STATISTICA 10, PAST 2.17 and PRIMER 9 softwares. The crab species richness recorded in the studied stations was compared using the Sander's rarefaction method [37]. Two non-parametric abundance-based estimators of species richness, the Chao 1 and the first-order jackknife and one non-parametric incidence-based estimator of species richness, the second-order jackknife, were used to estimate the potential number of crab species (observed and unseen) from samples and evaluate the sampling effort which is the ratio between observed species richness and theoretical species richness.

The species diversity of each community is evaluated using Shannon-Weaver, Margalef and Menhinick indices [38, 39, 40] while site evenness is evaluated using the Pielou's index [41].

\section{RESUlts AND Discussion}

\subsection{Opinion of the Study Site Habitants}

A total of 424 habitants of the study sites were interviewed (68.2\% men and $31.84 \%$ women). In Wouri estuary, 180 persons were interviewed, 82 persons in Mouanko, 51 in Kribi, 42 in Londji, 34 in Limbe and 35 in Tiko. The mean age of respondents is $28 \pm 1.2$ years for women (dominated by women farmer) and $35 \pm 0.6$ years for men (dominated by wood cutters). Destructive activities (wood harvesting and sand extraction) are mostly done by men while women are frequently exerting less destructive activities (fishing and agriculture). Education level is higher for men (56\% of respondents) than for women ( $22 \%$ of respondents). Women education level is weak probably for religious and economic reasons. Education level for two genders is higher in the Wouri estuary stations $(65 \%$ of respondents) with regards of existence of various primary secondary and high schools in all villages. Access to basic social amenities, such as drinking water, schools and health centers is scarce and alternative livelihood opportunities are practically non-existent in the others stations.

Data allows noting an acute degradation of mangrove stands in Cameroon: nine disturbed stations (D $>50 \%$ ) and eight not disturbed stations (D < 50\%) (Table 1). Mean duration of mangrove degradation in the stations is about 5 years. In all stations, wood harvesting (50.3\%) is the principal cause of mangrove destruction; follow by sand and gravels extraction (26\%). Exploitation of mangroves for fuel wood, charcoal production, construction and other uses have been identified as an important pervasive and intrusive threat to this ecosystem [42]. However, the extent of damage depends on intensity, persistence and periodicity of the disturbance [43]. In contrast, the little damage observed in not disturbed stations is probably due to their proximity with the terrestrial evergreen forest from which people collect wood for subsistence needs. Wood harvesting making place to ancillary activities such as agriculture (12.5\%), dwellings (5.4\%), breeding (3.1\%), brackish water aquaculture (1.5\%) and Non-Timber Forest Products (NTFPs) (1.2\%). Moreover, damming up activities (for housing) followed by excavation of sediments (by sand extraction) also has an impact on mangrove biodiversity loss through the ground modification and habitat loss for some animals [19]. Human activities are known to have a massive impact on mangrove ecosystem, especially through deforestation [44]. These impacts can significantly transform the forests, triggering a negative cascade effect on the whole ecosystem assemblage leading to a reduction of biodiversity and functionality [45, 46,47].

Table1. Station characteristics

\begin{tabular}{|c|c|c|c|c|c|}
\hline Mangrove state & Stations & $\begin{array}{l}\text { Sampling } \\
\text { effort }(\%)\end{array}$ & $\begin{array}{l}\text { species } \\
\text { richness }\end{array}$ & D $(\%)$ & $\begin{array}{c}\text { Major anthropogenic } \\
\text { activity }\end{array}$ \\
\hline \multirow{8}{*}{ 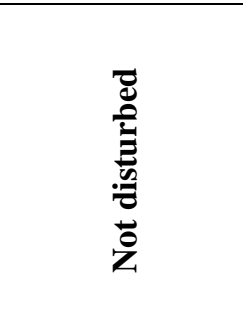 } & Londji I & 72.50 & 11 & 48 & Wood cut \\
\hline & Londji II & 90 & 10 & 42 & Wood cut \\
\hline & Yoyo I & 91.33 & 10 & 30 & Fishing \\
\hline & YoyoII & 84.25 & 9 & 41 & Fishing \\
\hline & Mbiako & 90.25 & 6 & 20 & Fishing \\
\hline & Avion beach & 66.75 & 8 & 34 & Wood cut \\
\hline & Appolo beach & 82.75 & 8 & 45 & Wood cut \\
\hline & Mile six beach & 89.50 & 8 & 49 & Wood cut \\
\hline \multirow{4}{*}{ 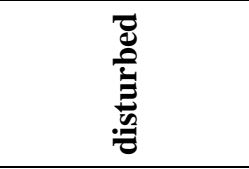 } & Bois de Singe & 100 & 8 & 88 & Wood cut \\
\hline & Essenguè & 100 & 13 & 91 & Wood cut \\
\hline & Pont du Wouri & 80.70 & 7 & 64 & Wood cut \\
\hline & Mpalla & 93.50 & 10 & 66 & Wood cut \\
\hline
\end{tabular}


Effect of Anthropogenic Activities on Mangrove Crab Diversity in Cameroon Atlantic Coast

\begin{tabular}{|l|l|c|c|c|c|}
\hline \hline & Nziou & 81 & 9 & 78 & Sand and gravel extraction \\
\cline { 2 - 6 } & Bonamoung & 94.50 & 8 & 67 & Sand and gravel extraction \\
\cline { 2 - 6 } & Bonagang & 84 & 7 & 52 & Sand and gravel extraction \\
\cline { 2 - 6 } & Bon'Ewonda & 100 & 8 & 56 & Sand and gravel extraction \\
\cline { 2 - 6 } & Down beach & 81 & 9 & 64 & Wood cut \\
\hline
\end{tabular}

Wood harvesting activity is significantly frequent in Essenguè station (37\%), Mpalla (35\%), Londji I (68\%), Londji II (59\%), Wouri bridge (31\%), Avion beach (42\%), Down beach (38\%), Apollo beach (47\%) and Mile six beach (34\%). Sand and gravel extraction is dominant in Nziou, Bonamouang, Bonagang and Bon' Ewonda stations for 53\%, 49\%, 36\% and $44 \%$ of respondents respectively. Fishing with $48 \%, 56 \%$ and $34 \%$ of respondents dominates in Mbiako, Yoyo I and Yoyo II stations respectively.

Rhizophora spp. (74.3\%) followed by Avicennia germinans (20.7\%) appear the two most threatened plant species. The edible crabs (58.4\%) such as Cardisoma spp. are threatened animal species. Rhizophora spp. still called (red mangroves) is dominant and strongly marketed or directly used in the households for subsistence needs [48]. In the households, wood is used as firewood, house construction, fish smoking, clothes industry, traditional canoe construction and paddles, etc. [49,50]. In not disturbed stations (Londji and Mouanko) specially in the villages of Yoyo I, Yoyo II and Mbiako fishing and fish smoking are the major economic activities and so, Rhizophora spp. is much snuffed because content resin and to be burned in a fresh state [51,14]. In these villages, approximately $62 \%$ of annual fuel-wood harvest is used to smoke fish (ref).

\subsection{Crab Diversity}

Table2. Crab species harvested in the mangrove forests of Cameron

\begin{tabular}{|c|c|c|}
\hline Families & Species & $\begin{array}{c}\text { Number of individuals } \\
\text { harvested }\end{array}$ \\
\hline \multirow{2}{*}{ Gecarcinidae } & Cardisoma armatum Herklots, 1951 & 103 \\
\hline & Cardisoma guanhumi Latreille, 1828 & 11 \\
\hline \multirow{4}{*}{ Grapsidae } & Pachygrapsus gracilis Saussure, 1858 & 30 \\
\hline & Pachygrapsus transversus Gibbes, 1850 & 475 \\
\hline & Goniopsis cruentata A. Milne-Edwards, 1867 & 144 \\
\hline & Goniopsis pelii Herklots, 1851 & 331 \\
\hline Macrophthalmidae & Macrophthalmus sp. & 19 \\
\hline Majidae & Maja squinado Herbst, 1788 & 4 \\
\hline \multirow{3}{*}{ Ocypodidae } & Ocypode africana De Man, 1881 & 20 \\
\hline & Ocypode cursor Linnaeus, 1758 & 11 \\
\hline & Uca tangeri Eydoux, 1835 & 549 \\
\hline Panopeidae & Panopeus africanus A. Milne-Edwards, 1867 & 8 \\
\hline \multirow{2}{*}{ Portunidae } & Portunus validus Herklots, 1951 & 54 \\
\hline & Callinectes pallidus Rochebrune, 1883 & 24 \\
\hline \multirow{10}{*}{ Sesarmidae } & Armases elegans Herklots, 1951 & 117 \\
\hline & Chiromantes buettikoferi De Man, 1883 & 226 \\
\hline & Chiromantes angolense Brito Capello, 1864 & 425 \\
\hline & Metagrapsus curvatus Herklots, 1951 & 632 \\
\hline & Perisesarma alberti Herklots, 1951 & 709 \\
\hline & Perisesarma huzardi Herklots, 1951 & 777 \\
\hline & Perisesarma kamermani De Man, 1883 & 1580 \\
\hline & Sesarma sp.1 & 224 \\
\hline & Sesarma sp.2 & 76 \\
\hline & Sesarma sp.3 & 93 \\
\hline Varunidae & Helice sp. & 5 \\
\hline
\end{tabular}

A total of 6643 specimen of crabs, comprising 25 species belonging to 9 families and 16 genera were collected (Table 2). Significant differences in terms of species richness and abundance between stations were observed (Mann-Whitney test: $U=95$ and 77 respectively, $n=17 ; p<0.005$ ). The sampling effort was relatively high and above $85.2 \%$. The rarefaction curve of crab species richness collected according to the number of stations was obtained in Figure 2. The species richness grows proportionally with increase of stations number until reaching an asymptote. Indeed, for all stations, the observed crab richness was still underestimated. The sampling effort also confirmed that more 
crab species still remain to be caught in our study area. Londji I, Down Beach and Wouri bridge stations appear weakly sampling $(\mathrm{E}<81 \%)$, while in Bois de singe, Bon'Ewonda and Essenguè stations, sampling effort reach $100 \%$.

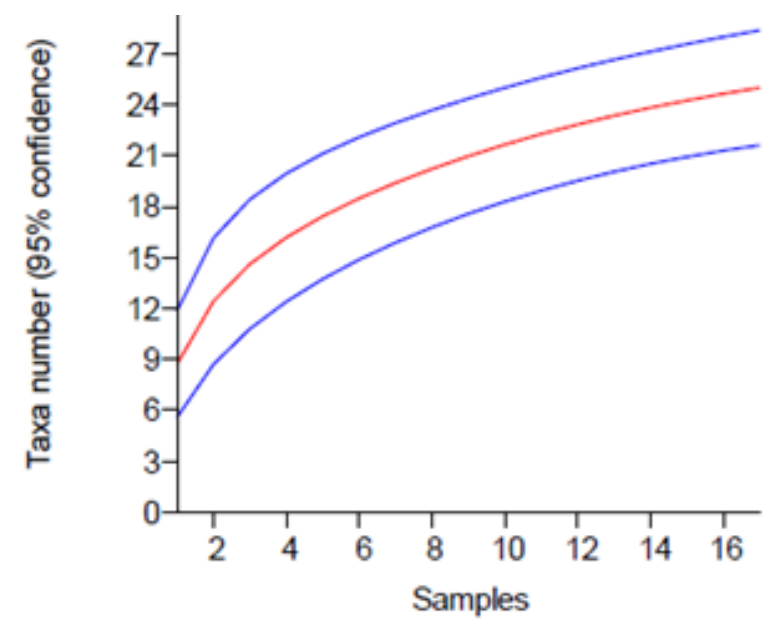

Figure2. Rarefaction curve (red) of crab species richness collected according to station areas with a confidence (blu) of $95 \%$

The Sesarmidae family was both the most species richness with 10 species and the most abundant taxa (80.7\% of individuals). Grapsidae family is represented by four species and Ocypodidae family by three species. Gecarcinidae and Portunidae families contain each two species, Macrophthalmidae, Majidae, Panopeidae and Varunidae families are represented only by one species each. This prevalence of Sesarmidae family had been also observed in several mangrove of the world. In peninsular Malaysia, 41 species were counted [3], 30 species in the East of Asia [52], including 46 species in India in particular [53], 23 species in Americas from which only 5 are associated the mangroves [54], 7 species in Western Africa [55] including 5 species in Guinea [56]. Species of this family constitute the key functioning elements of this ecosystem [57,58].

The highest values are recorded in the Essenguè, Mpalla, Londji I and Londji II stations with $\mathrm{H}^{\prime}>2$; $\mathbf{J}$ $>0.8 ; \mathrm{Mg}>1.3$ and $\mathrm{Mn}>0.35$ (Table 3). These stations are well diversified and several species are better represented. The lowest values are recorded in the Wouri Bridge station $\left(\mathrm{H}^{\prime}=1.38 ; \mathrm{I}=0.71 ; \mathrm{Mg}\right.$ $=0.95$ and $\mathrm{Mn}=0.30)$ and Bonangang station $\left(\mathrm{H}^{\prime}=1.58 ; \mathrm{J}=0.81 ; \mathrm{Mg}=1\right.$ and $\left.\mathrm{Mn}=0.35\right)$. In these stations, crabs are less distributed and 3 or 4 species are largely dominant. Shannon-Weaver and Pielou indices increase with species richness and sample size. Margalef and Menhinick indices give the same results, but are independent of sample size. Thus, the low values of these indices obtained in certain stations are allotted to the low number of species present and environmental degradation due to the anthropogenic pressures and biotic factors [59].

Table3. Crab diversity and species richness in the sampling stations

\begin{tabular}{|c|c|c|c|c|c|c|c|c|c|c|c|c|c|c|c|c|c|}
\hline \multirow{2}{*}{ Parameters } & \multicolumn{6}{|c|}{ Wouri Estuary } & \multicolumn{3}{|c|}{ Mouanko } & \multicolumn{2}{|c|}{ Kribi } & \multicolumn{2}{|c|}{ Londji } & \multicolumn{2}{|l|}{ Tiko } & \multicolumn{2}{|c|}{ Limbe } \\
\hline & 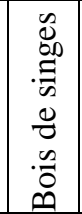 & 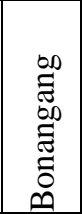 & 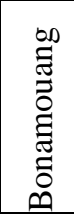 & 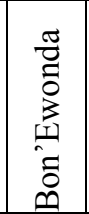 & 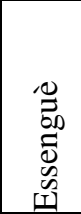 & 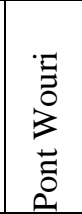 & 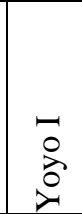 & $\begin{array}{l}= \\
\stackrel{0}{\partial} \\
\stackrel{\partial}{0}\end{array}$ & 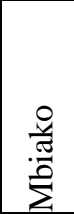 & $\begin{array}{l}\frac{\pi}{\bar{F}} \\
\stackrel{\tilde{L}}{\Sigma}\end{array}$ & $\frac{\vec{a}}{\mathrm{a}}$ & $\begin{array}{l}- \\
: \bar{\sigma} \\
\bar{\sigma} \\
\end{array}$ & 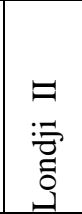 & 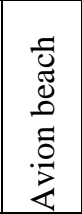 & 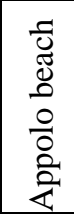 & 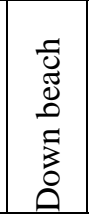 & 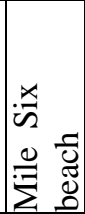 \\
\hline $\mathbf{P}$ & 6 & 7 & 6 & 9 & 8 & 6 & 8 & 6 & 9 & 11 & 8 & 8 & 6 & 6 & 6 & 7 & 6 \\
\hline Ss $\left(\mathbf{m}^{2}\right)$ & 96 & 112 & 96 & 144 & 128 & 96 & 128 & 96 & 144 & 176 & 128 & 128 & 96 & 96 & 96 & 112 & 96 \\
\hline $\mathbf{N}$ & 713 & 406 & 710 & \begin{tabular}{|l|}
448 \\
\end{tabular} & \begin{tabular}{|l|l|}
1277 \\
\end{tabular} & 543 & 333 & 448 & \begin{tabular}{|l|}
229 \\
\end{tabular} & 318 & 358 & 173 & 273 & 97 & 104 & \begin{tabular}{|l|}
127 \\
\end{tabular} & 90 \\
\hline $\mathbf{S}$ & 8 & 7 & 8 & 8 & 13 & 7 & 10 & 9 & 6 & 10 & 9 & 11 & 10 & 8 & 8 & 9 & 8 \\
\hline$A\left(\right.$ per $\left.m^{2}\right)$ & 7.43 & 3.63 & 7.4 & 3.11 & 9.98 & 5.66 & 2.6 & 4.67 & 1.56 & 1.81 & 2.8 & \begin{tabular}{|l|}
1.4 \\
\end{tabular} & 2.84 & \begin{tabular}{|l|}
1.1 \\
\end{tabular} & 1.08 & 1.13 & 1 \\
\hline D & 0.22 & 0.24 & \begin{tabular}{|l|}
0.22 \\
\end{tabular} & \begin{tabular}{|l|}
0.15 \\
\end{tabular} & \begin{tabular}{|l|}
0.15 \\
\end{tabular} & 0.34 & \begin{tabular}{|l|}
0.16 \\
\end{tabular} & 0.25 & \begin{tabular}{|l|}
0.20 \\
\end{tabular} & \begin{tabular}{|l|}
0.15 \\
\end{tabular} & \begin{tabular}{|l|}
0.16 \\
\end{tabular} & \begin{tabular}{|l|}
0.13 \\
\end{tabular} & \begin{tabular}{|l|}
0.13 \\
\end{tabular} & 0.15 & \begin{tabular}{|l|l|}
0.17 \\
\end{tabular} & \begin{tabular}{|l|}
0.16 \\
\end{tabular} & \begin{tabular}{|l|}
0.16 \\
\end{tabular} \\
\hline 1-D & 0.78 & 0.76 & \begin{tabular}{|l|}
0.78 \\
\end{tabular} & 0.85 & 0.85 & 0.66 & 0.84 & 0.75 & 0.80 & 0.85 & 0.84 & 0.87 & \begin{tabular}{|l|} 
\\
\end{tabular} & 0.85 & 0.83 & 0.84 & 0.84 \\
\hline $\mathrm{H}^{\prime}$ & 1.72 & 1.58 & 1.72 & 1.96 & 2.18 & 1.38 & 1.98 & 1.69 & 1.68 & 2.02 & 1.96 & 2.20 & 2.17 & 1.98 & 1.92 & 1.97 & 1.92 \\
\hline Mn & 0.30 & 0.35 & 0.30 & 0.38 & 0.36 & 0.30 & 0.55 & 0.43 & 0.40 & 0.50 & 0.48 & 0.84 & 0.61 & 0.81 & 0.78 & 0.80 & 0.84 \\
\hline Mg & 1.07 & 1.00 & \begin{tabular}{|l|}
1.07 \\
\end{tabular} & 1.15 & 1.68 & 0.95 & 1.55 & 1.31 & 0.92 & 1.39 & 1.36 & 1.94 & 1.60 & 1.53 & 1.51 & 1.65 & $\mid 1.56$ \\
\hline $\mathbf{J}$ & 0.83 & 0.81 & 0.83 & 0.94 & 0.85 & 0.71 & 0.86 & 0.77 & 0.93 & 0.92 & 0.89 & 0.92 & 0.94 & 0.95 & 0.92 & 0.90 & 0.92 \\
\hline
\end{tabular}


P: Number of $4 x 4 \mathrm{~m}$ plots; Ss: Site surface; $\boldsymbol{N}$ : Sample size; $\boldsymbol{S}$ : Species richness; $\boldsymbol{A}:$ Absolute density; D: Dominance index; 1-D: Simpson index; H': Shannon Weaver index; Mn: Menhinick index; Mg: Margalef index; J: Pielou index

\subsection{Impacts of Deforestation on Crab Composition}

In the harvested crabs, 3879 specimens comprising 20 species belonging to 8 families were counted in not disturbed stations. Sesarmidae family are represented by 10 species, Gecarcinidae, Grapsidae and Portunidae families by two species each, Ocypodidae, Macrophthalmidae, Majidae, Panopeidae and Varunidae families by one species each. In disturbed stations, 2768 specimens, grouped in 19 species and 6 families were recorded. Sesarmidae are represented by 8 species, Grapsidae by four species, Ocypodidae by three species, Portunidae by two species, and Gecarcinidae by one species each. There is a significant difference between the two stations only in term of abundance (Mann-Whitney test $\mathrm{U}=80 ; \mathrm{n}=17 ; \mathrm{p}<0.005)$.

According to deforestation, crab assemblage shown a considerable variation in terms of species richness and abundance (Figure 3). Six species Cardisoma guanhumi Latreille, 1828, Helice sp., Macrophthalmus sp., Panopeus africanus A. Milne-Edwards, 1867, Sesarma sp.2 and Sesarma sp.3 species are strictly pledged in not disturbed stations. In the scale of this study, these species could be regarded as bio-indicators species of stable mangroves, but additional and thorough studies should be conducted to check this assumption. Four crab families (Macrophthalmidae, Majidae, Panopeidae and Varunidae) were not represented in disturbed stations and the number of species of Sesarmidae (from 10 to 8 species) and Gecarcinidae (from 3 to 1 species) families fallen down within disturbed stations. The decrease of species number of Sesarmid crabs was also reported in Kenya (East Africa) in the adjacent gap areas, where Sesarmid crabs were totally absent in the absence of mangrove trees [60].

Abundances of species Chiromantes buettikoferi De Man, 1883 (from 4.5 to $2.6 \%$ of specimens), Metagrapsus curvatus Herklots, 1951 (from 12 to $7.68 \%$ of specimens), Sesarma sp. (from 4.3 to $2.7 \%$ of specimens), Chiromantes angolense Brito Capello, 1864 (from 10.73 to $3.30 \%$ of specimens) and Perisesarma alberti Herklots, 1951 (from 16.61 to $6.42 \%$ of specimens) decreased within disturbed stations. Sesarmidae and Portunidae families' abundance decrease from 84.83 to $75.87 \%$ of specimens and from 1.7 to $0.8 \%$ of specimens respectively throughout deforestation. Conversely, Gecarcinidae, Ocypodidae and Grapsidae families' abundance increased from 1.12 to $2.14 \%$ of specimens, 1.37 to $2.83 \%$ of specimens and 9.83 to $18.25 \%$ of specimens respectively.

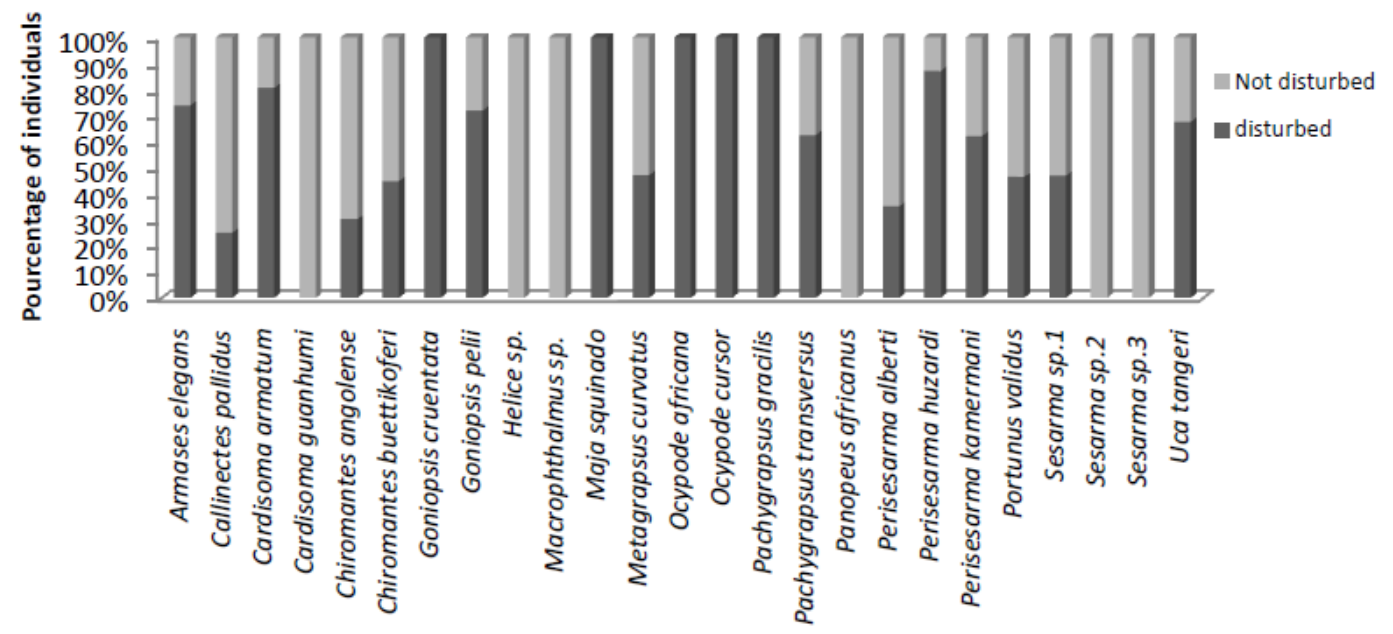

Figure3. Variation of crab species abundances according to not disturbed and disturbed stations

The importance of vegetation and channel distance on crab distribution has been described in the Wouri Estuary mangroves [29]. Vegetation is highly dominated by Rhizophora plant and that zone is the most diversified (18 crab species) which, two crab Helice sp. and Maja squinado Herbst, 1788 were strictly pledged. Some herbivorous crab families predominantly Sesarmidae family are known to depredate on Rhizophora propagules [61,62]. Therefore, the overexploitation of Rhizophora spp. lead the loss of some indigenous crabs (Helice sp., Maja squinado) and feed dependant crabs of this plant. Furthermore, Cardisoma spp. and Uca tangeri Eydoux, 1835 species are the most terrestrial crabs, because they live essentially close to back mangroves. With regards to anthropogenic activities such 
as agriculture, dwellings, breeding, aquaculture and wood harvested, these terrestrial crabs are mainly threatened more than Callinectes pallidus Rochebrune, 1883 and Portunus validus Herklots, 1951, crabs found only near channels (marine crabs). The studies relating to deforestation impact on crab biodiversity are poorly widespread. Thus, the disappearance of crabs could be influences a significant degree of nutriments cycle, ventilation and drainage of mangrove grounds, through the fall of bioturbation activities necessary to function of this ecosystem and mangrove forest growth and productivity fall down [1,57]. According to [15], the greatest current threat to mangrove survival however is deforestation and such continuing losses must be considered in tandem with the impact of climate change.

\section{CONCLuSion}

In Cameroon, mangrove crabs is diversified with 25 species. Sesarmidae family is the most diverse and the most abundant taxa. Mangrove forests undergo deforestation, which can reduce their crab diversity and prevent them from fully performing their multiple roles. Six crab Cardisoma guanhumi, Helice sp., Macrophthalmus sp., Panopeus africanus, Sesarma sp.2 and Sesarma sp.3 species appear as indigenous species in not disturbed stations. Abundances of species Chiromantes buettikoferi, Metagrapsus curvatus, Sesarma sp., Chiromantes angolense and Perisesarma alberti decreased throughout deforestation. Species of Ocypodidae, Gecarcinidae and Grapsidae families seem to be more resistant to deforestation than Sesarmidae and Portunidae families. Furthermore, the indigenous species Maja squinado and Helice sp. of Rhizophora spp. zone and Cardisoma spp. and Uca tangeri (terrestrial crabs) are the mainly threatened. However, some environmental factors have an influence on diversity of macrobenthos in mangroves. It would be interesting to follow the dynamics of crabs in relation to physical and chemical variables and domestic or industrial wastewater.

\section{ACKNOWLEDGEMENT}

We gratefully acknowledge the IDEA WILD for field equipment grant of this work.

\section{REFERENCES}

[1] Cannicci S., Burrows D., Fratini S., Smith III T. J., Offenberg J., and Dahdouh-Guebas F. Faunal impact on vegetation structure and ecosystem function in mangrove forests: a review. Aqua. Bot. 89(2), 186-200 (2008).

[2] Ravichandran S. and Wilson F.S. Variations in the crab diversity of the mangrove environment from Tamil Nadu, Southeast coast of India. VLIZ Special Publication 57: 152 (2012).

[3] Lee S.Y. Ecological role of grapsid crabs in mangrove ecosystems: a review. Mar. Freshw. Res. 49, 335-343(1998).

[4] Cannicci S., Bartolini F., Dahdouh-Guebas F., Fratini S., Litulo C., Macia A. and Paula J. Effects of urban wastewater on crab and mollusc assemblages in equatorial and subtropical mangroves of East Africa. Estuar. Coast. Shelf sci. 84 (3), 305-317(2009).

[5] Ng P.K.L., Guinot D. and Davie P.J.F. Systema Brachyuroran: part I. An annotated checklist of extant Brachyuran crabs of the world. Raffles bulletin of Zoology 17, 1-286 (2008).

[6] Smith F.N., Wilcox C. and Lessmann, J.M. Fiddler crab burrowing affects growth and production of the white mangrove (Laguncularia racemosa) in a restored Florida coastal marsh. Mar. Biol. 156, 2255-2266 (2009).

[7] Sousa W.P. and Dangremond E.M. Trophic interactions in coastal and estuarine mangrove forest ecosystems, in: E. Wolanski, D.S. McLusky (Eds.) Treatise on Estuarine and Coastal Science, vol. 6 Academic Press, Waltham, pp. 43-93 (2011).

[8] Simoni R., Giomi F., Spigoli D., Pörtner H.O. and Cannicci S. Adaptations to semi-terrestrial life in embryos of East African mangrove crabs: a comparative approach. Mar. Biol. 1-10 (2013).

[9] Lee, S.Y. Mangrove macrobenthos: assemblages, services, and linkages. J. Sea Res. 59(1), 16-29 (2008).

[10] Dahdouh-Guebas F., Koedam N., Satyanarayana B., Cannicci S. Human hydrographical changes interact with propagule predation behaviour in Sri Lankan mangrove forests. J. Exp Mar. Biol. Ecol. 399(2), 188-200 (2011).

[11] Ferreira T.O., Otero X.L., Vidal-Torrado P., Macías F. Effects of bioturbation by root and crab activity on iron and sulfur biogeochemistry in mangrove substrate. Geoderma 142,36 - 46 (2007). 
[12] Kristensen E. Mangrove crabs as ecosystem engineers; with emphasis on sediment processes. J. Sea Res. 59 (1), 30-43(2008).

[13] Andreetta A., Fusi M., Cameldi I., Cimò F., Carnicelli S. and Cannicci, S. Mangrove carbon sink. Do burrowing crabs contribute to sediment carbon storage? Evidence from a Kenyan mangrove system. J. Sea Res. 85, 524-533 (2013).

[14] Walters B.B., Ro“nnba“ck P., Kovacs J.M., Crona B., Hussain S.A., Badola R., Primavera J.H., Barbier E. and Dahdouh-Guebas F. Ethnobiology, socio-economics and management of mangrove forests: A review. Aqua. Bot. 89, 220-236 (2008).

[15] Alongi D.M. The impact of climate change on mangrove foress. Curr. Clim. Change Rep. 1, 3039 (2015).

[16] Alemagi D. The oil industry along the Atlantic coast of Cameroon: assessing impacts and possible solutions. Resour. Pol. 32(3), 135-145(2007).

[17] Din N., Saenger P., Priso R.J., Dibong D.S. and Blasco F. Logging activities in mangrove forests: a case study of Douala Cameroon. Afr. J. Environ. Sci. Techn. 2(2), 22-30 (2008).

[18] Nfotabong-Atheull A., Din N. and Dahdouh-Guebas F. Qualitative and Quantitative Characterization of Mangrove Vegetation Structure and Dynamics in a Peri-urban Setting of Douala (Cameroon): An Approach Using Air-Borne Imagery. Estuar. Coasts 1-12 (2013).

[19] Nfotabong-Atheull A., Din N., Koum L.G.E., Satyanarayana B., Koedam N. and DahdouhGuebas F. Assessing forest products usage and local residents' perception of environmental changes in peri-urban and rural mangroves of Cameroon, Central Africa. J. Ethnobiol. Ethnomedi. 7(1), 41(2011).

[20] Penha-Lopes G., Torres P., Narciso L., Cannicci S. and Paula, J. Comparison of fecundity, embryo loss and fatty acid composition of mangrove crab species in sewage contaminated and pristine mangrove habitats in Mozambique. J. Exp. Mar. Biol. Ecol. 381(1), 25-32(2009).

[21] Bartolini F., Cimò F., Fusi M., Dahdouh-Guebas F., Lopes G.P. \& Cannicci S. The effect of sewage discharge on the ecosystem engineering activities of two East African fiddler crab species: Consequences for mangrove ecosystem functioning. Mar. Environ. Res. 71(1), 5361(2011).

[22] Twilley R.R., Pozo M., Garcia V.H., Rivera-Monroy V.H., Zambrano R. and Bodero A. Litter dynamics in riverine mangrove forests in the Guayas river estuary, Ecuador. Oecologia 111, 109122 (1997).

[23] Ashton E.C., Hogarth P.J. and Macintosh D.J. A baseline study of the diversity and community ecology of crab and molluscan macrofauna in the Semantan Mangrove forest, Sarawak, Ma1aysia. J. Trop. Ecol. 19, 127-142 (2003).

[24] Brykov V.A., Kukhlevskil A.D., Shevliakov E.A., Kinas N.M. and Zavarina L.O. Sex ratio control in pink salmon (Oncorhynchus gorbuscha) and chum salmon (O. keta) populations: the possible causes and mechanisms of changes in the sex ratio. Genetika 44, 906-912 (2008).

[25] Erickson A.A., Feller I.C., Paul V.J., Kwiatkowski L.M. and Lee W. Selection of an omnivorous diet by the mangrove tree crab Aratus pisonii in laboratory experiment. J. Sea Res. 59, 59-69 (2008).

[26] Herteman M. Evaluation des capacités bioremédiatrices d'une mangrove impactée par des eaux usées domestiques: Application au site pilote de Malamani, Mayotte. Doctorat de l'Université de Toulouse, $330 \mathrm{p}$ (2010).

[27] Esenowo I.K. and Ugwumba A.A.A. Composition and abundance of macrobenthos in Majidun River, Ikorordu Lagos State, Nigeria. Res. J. Biol. Sci. 5 (8), 556-560 (2010).

[28] Ngo-Massou V.M., Essome-Koum G.L., Ngollo-Dina E. and Din N. Composition of macrobenthos in the Wouri River estuary mangrove, Douala, Cameroon. Afri. J. Mar. Sci. 34(3), 349-360 (2012).

[29] Ngo-Massou V.M., Essomè Koum G.L., Kotte M.E. and Din N. Biology and Distribution of Mangrove Crabs in the Wouri River Estuary, Douala, Cameroon. J.WA.R.P. 6, 236-248 (2014).

[30] Vandeputte M., Quillet E. and Chatain, B. Are sex ratio in wild European sea bass (Dicentrarchus labrax) populations biased? Aquatic Living Resources 25, 77-81 (2012).

[31] Din, N., Ngo-Massou, V.M., Kotte, M.E., Essoh Mongo, M.C. \& Essomè-Koum, G.L. 2014. Evolution of Mangrove crabs distribution in the atlantic coast of Cameroon. In: Ardovi C. (ed) Crabs: Global diversity, behavior and environmental threats. Nova publishers, New york, Pp 191. 
[32] Giresse P., Megope-Foonde J.P., Ngueutchoua G., Aloisi J.C., Kuete M. and Monteillet J.. Carte sédimentologique du plateau continental du Cameroun à 1:200000. ORSTOM, Paris, France (1996).

[33] Joana M., Jordan O. and Oliveira R.F. Comparison of non-invasive methods for quantifying population density of the Fiddler crab Uca tangeri. J. Mar. Biol. Association 83, 981-982 (2003).

[34] Bouchet P., Olivier P. and Le Guyader, H. Des voyages de cook à l'expédition Santo: un renouveau des explorations naturalistes des îles du Pacifique. Le journal de la société des océanistes 126-127 (2006).

[35] Manning R.B. \& Holthuis, L.B. 1981. West African Brachyuran Crabs (Crustacea: Decapoda). Smithsonian contributions to Zoology, number 306.

[36] Dajoz R. Précis d'écologie. 5 ème édition, Ed. Dunod, Paris. 505 p (1985).

[37] Longino J.T., Coddington J. and Colwell, R.K. The ant fauna of a Tropical rain forest: estimating species richness three different ways. Ecology 83, 689-702 (2002).

[38] Shannon C.E. and Weaver W. The mathematical theory of communication. Urbana University Press, Illinois, pp 117 (1963).

[39] Margalef R. Life forms of phytoplankton as survival alternatives in an unstable environment. Oceanologica Acta 1, 493-509 (1958).

[40] Menhinick E.P. A comparison of some species-individuals diversity indices applied to samples of field insects. Ecology 45, 859-861 (1964).

[41] Pielou E.C. An introduction to Mathematical Ecology (Witley-Interscience ed.). New York, Witley-Interscience (1969).

[42] Feka, N.Z. and Manzano, M.G. T he implications of wood exploitation for fish smoking on mangrove ecosystem conservation in the South West Province, Cameroon. Trop. Conserv. Sci. 1: 222-235 (2008).

[43] Hauff R.D., Ewel K.C. and Jack J. Tracking human disturbance in mangroves: estimating harvest rates on a Micronesian Island. Wetlands Ecol. Manage. 14, 95-10 (2006).

[44] Hutchison J., Manica A., Swetnam R., Balmford A. and Spalding M. Predicting global patterns in mangrove forest biomass. Conservation Letters (2013).

[45] Worm B., Barbier E.B., Beaumont N., Duffy J.E., Folke C., Halpern B.S. and Watson R. Impacts of biodiversity loss on ocean ecosystem services. Science 314 (5800), 787-790 (2006).

[46] Duke N.C., Meynecke J.O., Dittmann S., Ellison A.M., Anger K., Berger U., Cannicci S., Diele K., Ewel K.C., Field C.D., Koedam N., Lee S.Y., Marchand C., Nordhaus I. and DahdouhGuebas F. A world without mangroves? Science 317, 41-42 (2007).

[47] Butchart S.H., Walpole M., Collen B., van Strien A., Scharlemann J.P., Almond R.E. and Watson R. Global biodiversity: indicators of recent declines. Science 328 (5982), 1164-1168 (2010).

[48] Feka N.Z., Chuyong G.B. and Ajonina G.N. Sustainable utilization of mangroves using improved fish-smoking systems: a management perspective from the Douala-Edea wildlife reserve, Cameroon. Trop. Conserv. Sci. 4 (2), 450-468(2009).

[49] Ndenecho E.N. Economic value and management of mangrove forests in Cameroon. Int. J. Sustainable Develop. World Ecol. 14 (6), 618-625 (2007).

[50] Nfotabong-Atheull, A.N., Din, N., Longonje, S.N., Koedam, N. and Dahdouh-Guebas, F. J. Ethnobiol. Ethnomedi. 5, 35 (2009).

[51] CWCS Cameroon Wildlife Conservation Society Douala-Edea Forest Project: Report of activities, Mouanko, Cameroon (2001).

[52] Ellison A.M. Managing mangroves with benthic biodiversity in mind: moving beyond roving banditry. J. Sea Res. 59(1), 2-15(2008).

[53] Ravichandran and Kannupandi. Biodiversty of crabs in Pichavaram mangrove environment. Zoological Survey of India. National Symposium on conservation and Valuation of marine Biodiversity 331-340 (2007).

[54] Abele L.G. A review of the grapsid crab genus Sesarma (Crustacea: Decapoda: Grapsidae) in America, with the description of a new genus. Smithsonian Contributions to Zoology 527, 1-60 (1992). 
[55] Guiral D., Albaret J.J., Baran E., Bertrand F., Debenay J.P., Diouf P.S., Guillou J.J., Le Loeuff P., Montoroi J.P. and Sow M. Rivières du Sud: Sociétés et Mangroves Ouest- africaines. Volume 1, chap. 2: Les écosystèmes à mangrove (1999).

[56] Cumberlidge N. Inventaire rapide des crustacés décapodes de la préfecture de Boké en Guinée. In: Wright HE, McCullough J, Saliou Diallo M (eds) Un inventaire biologique rapide de la préfecture de Boké dans le nord-ouest de la Guinée. RAP Bulletin of Biological Assessment 41. Washington, DC: Conservation International; Pp 38-46 (2006).

[57] Smith T.J., Boto K., Frusher S., Giddins R. Keystone species and mangrove forest dynamics: the influence of burrowing by crabs on soil nutrient status and forest productivity. Estuar. Coast. Shelf Sci. 33, 419-432 (1991).

[58] Boon P.Y., Ye D.C.J. and Todd P.A. Feeding ecology of two species of Perisesarma (Crustacea: Decapoda: Brachyura: Sesarmidae) in Mandai mangroves, Singapore. J. Crust. Biol. 28, 480-484 (2008).

[59] Ravera O. A comparison between diversity, similarity and biotic indices applied to the macroinvertebrate community of a small stream: The Ravella river (Como Province, Northern Italy). Aquat. Ecol. 35, 97-107 (2001).

[60] Van Nedervelde F., Cannicci S., Koedam N. and Bosire J. What regulates crab predation on mangrove propagules? Acta Oecologica 63, 63-70 (2015).

[61] Skov M.W. and Hartnoll R.G. Paradoxical selective feeding on a low nutrient diet: why do crabs eat leaves? Oecologia 131, 1-7 (2002).

[62] Masagca J.T. Feeding Ecology of tree-climbing mangrove Sesarmid crabs from Luzon, Philippines. Biotropia 16 (1), 1 - 10 (2009).

\section{AUTHORS' BIOGRAPHY}

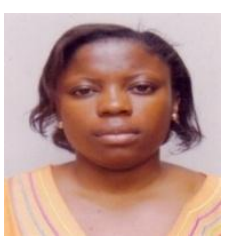

Vanessa Maxemilie Ngo-Massou, is a researcher in the Department of Botany, Faculty of Sciences, University of Douala, and in the department of Biological Sciences of the Higher Teacher Training College in the University of Yaounde I, in Cameroon. Areas of research: Zoology, Taxonomy, Ecology of mangroves crustaceans and mollusks, climate change.

Martin Kenne, Associate Profesor in the Department of Biology of Animal Organisms, Faculty of Science, University of Douala, Cameroon. Areas of research: Zoology, Entomology, invasive species, biopesticides, animal behavior and Neuroscience.

Alain Bertrand Dongmo, Associate Profesor in the Department of Biology of Animal Organisms, Faculty of Science, University of Douala, Cameroon. Areas of research: Physiology, pharmacology, plant and animal science and applied chemistry. 
Appendix1. Mangrove socio-economic survey questionnaire, Cameroon

\section{Identification of locality and respondents}

Number:

Date:.

locality

years ; Stay time in locality:

years;

..gender: $\quad \mathbf{F} \square \quad \mathbf{M} \square ; \quad$ Age

Civil statute: $\mathbf{M} \square \mathbf{S} \square \mathbf{D} \square \mathbf{W} \square$; Schooling level: $\mathbf{B} \square \mathbf{S} \square \mathbf{H} \square$;

Major activity:

\section{Characteristics of locality}

- Which are the majors activities harvested in mangrove?

Agriculture $\square$ breeding $\square$ Fishing $\square$ Dwellings $\square$ wood dealers $\square$ Wood cut $\square$

Sand and gravel extraction $\square$ brackish water aquaculture $\square$ Non-Timber Forest Products $\square$ House construction $\square$ Others Cited....

- Do you thing that our mangrove forests are changed? Yes $\square$ No $\square$

- If yes, since how many years?

$0-5$ years $\square \quad 5-10$ years $\square \quad 10-15$ years $\square \quad$ More than 15 years $\square$

- Actually what is the vegetation state?

$$
\text { Denser } \square \quad \text { less dense }
$$

-Actually what is the fauna state?

$$
\text { Denser } \square \quad \text { less dense } \quad \square
$$

- Which are the most threatened plant species?

Cited:

-Which are the most threatened fauna species?

Cited

- Do you use 'matanda' mangrove wood

$$
\text { Yes } \square \text { No } \square
$$

-If No, what other source of wood do you use

- If yes, what do you use it for?

Fish smoking $\square$ Cooking $\square$ sell $\square$ Building Banda $\square$ House construction $\square$

Beds $\square$ Others (please specify)

-Which is the mean reason of this mangrove change?

Agriculture $\square$ breeding $\square$ Fishing $\square$ Dwellings $\square$ Wood cut $\square$ wood dealers $\square$

Sand and gravel extraction $\square$ brackish water aquaculture $\square$ Non-Timber Forest Products $\square$

Climate change $\square$ Others Cited

- Do you harvest mangrove crabs in our locality? Yes $\square$ No $\square$

- If yes, what do you use it for?

Cooking $\square$ sell $\square$ Treatment $\square$ Fishing $\square$ Cosmetics $\square$ Others

- How many types of crabs do you know?

$$
1 \text { to } 2 \text { species } \square \quad 3 \text { to } 5 \text { species } \square \quad \text { more than } 5 \text { species }
$$

- Do you thing that mangrove crabs are threatened? Yes $\square$ No $\square$

If yes, why?. 